\title{
The possible role and position of social work as part of the arrival infrastructure
}

\author{
Special issue: Social work with asylum seekers, refugees and other displaced groups \\ across Europe
}

\begin{abstract}
In order to de-nationalise, de-'ethnicise' and de-'migranticise' migration studies, scholars are increasingly turning to space as a conceptual and empirical entry-point. Inspired upon the notion of the urban 'transition zone', initially coined by Chicago School urban sociologists in the 1930s, recent research re-focuses on the role of particular urban neighbourhoods as places of 'arrival' and 'gateways' that stimulate the social and spatial mobility of newcomers. In this paper we develop a friendly critique on the teleological and normative underpinnings of the notion of 'arrival neighbourhood' and propose the concept of 'arrival infrastructures' as an alternative. Arrival infrastructures are those parts of the broader urban fabric in which newcomers become entangled on arrival and where their future local or translocal social becomings are produced as much as negotiated. Starting from such an approach, we explore the possible role and position of social work as part of the arrival infrastructure. We argue that the concept of arrival infrastructures allows social workers to capture the broad range of actors involved in 'arriving' and to discuss their own position and role. Moreover, it demonstrates how arrival is always a provisional state of being, during which local or translocal futures are in preparation.
\end{abstract}

\section{Keywords}

Arrival infrastructures, social work with displaced groups, mobilities, informal social work actors, migration studies

\section{Introduction}

Brussels, February 2019. During the book presentation of 'Sociaal schaduwwerk. Over informele spelers in het welzijnswerk' [Social work in the shadow. About informal actors in social work], Daniel Alliët, the priest of the Church of Saint John the Baptist at the Brussels' Beguinage, testifies about his commitment to refugees, undocumented migrants and other vulnerable people. His church was occupied five times by undocumented migrants to draw attention to the problematic situation of refugees and other displaced groups in Belgium. He moreover shares his house with (undocumented) homeless people, and stood at the cradle of numerous social projects through which asylum seekers find food and shelter. 
Many members of the audience are equally involved in such initiatives, performing different forms of hospitality and opposing restrictive state policies and anti-immigrant trends. Some of them are social workers who work with asylum seekers or refugees. Others take part in citizen initiatives such as the Brussels based 'Citizens' Platform for Refugee Support', a movement that was created in 2015 and that offers meals, healthcare, accommodation, activities, education and psychological support to people who are forcibly displaced yet are not provided accommodation or assistance by the Belgian government. Still others support displaced people through their engagement in migrant associations, charities, faith-based organizations or online communities. At the same time, many examples can be given of citizens and politicians who strongly oppose to and actively mobilise against newcomers. In general, one can say that strong polarizations mark the way local contexts respond to the arrival and transit of asylum seekers and other displaced people in Europe and that different types of infrastructures are developed to move people along specific - normative - trajectories (Birk, 2017).

While social work literature has primarily considered the arrival and integration of newcomers as the exclusive domain of the state and of 'formal' social work organizations (Popescu \& Libal, 2018; Valtonen, 2016), the composition of the audience of the book presentation, arguably only a slice of reality, demonstrates the diversity of actors and organizations that are actually involved in the everyday support of displaced people. Research indeed indicates that civil society and other informal (trans)local actors often provide newcomers with a temporary or long-lasting safety net and with social capital (Beaumont \& Cloke, 2012; Schrooten, 2012; Törngren, Öberg, \& Righard, 2018; Van Dam \& Raeymaeckers, 2017). Besides material support in the form of food distribution or temporary housing, many of them also provide legal advice, orient newcomers to work, develop systems of mutual financial support, give people a voice and (de)politicise them in relation to particular matters of concern, to name only a few examples that are given during the book presentation.

A second major theme that emerges through the discussions that follow Daniel Alliët's testimony, is the fact that such forms of support often have a geographical and material logic, in the sense that expertise, relevant services and repertoires of action 'belong to' or can only be found or accessed in particular places or through interactions with particular materials. Some examples are places to connect to the World Wide Web (e.g. free WIFI spots), transport arrangements or numbers to call in case of an emergency to reduce the risks involved in moving (see also Hannam, Sheller, \& Urry, 2006; Raithelhuber, Sharma, \& Schröer, 2018). Besides 
these, local places that facilitate sociability and informal knowledge exchange such as bars, restaurants, hairdressers and ethnic shops can be crucial because of their accessibility and liberal language regimes (Blommaert, 2014). It is often through these specific places that migrants gain access to social networks, information and informally allocated resources (Meeus, 2017). Besides those semi-public spaces, the homes of family members, friends, acquaintances or fellow countrymen often prove to be fundamental not only in the support of short-term management of arrival, but also in the processes of social, economic and cultural integration. Even though the role of such places, infrastructures or systems has been explored in migration literature, they are hardly ever taken into account and even remain a blind spot in social work literature as well as practice, despite their essential function in the mobility, the reception and support of people on the move and the negotiation of their future trajectories (see Boccagni, 2015; Schuermans, Schrooten, \& De Backer, 2019 for some notable exceptions). It appears then that social work with asylum seekers, refugees and other displaced groups lacks a concept that has enough bandwidth to understand and engage with the sociospatial diversity of forms of social organization that already exist and to discuss its own role and position amidst such situated socio-material assemblages of support.

One possible way is to approach the issue with a territorial lens. Recent research in anthropology, sociology, social geography, migration studies and urban studies re-focuses for example on the role of particular urban neighbourhoods as places of 'arrival' and as 'gateways' that stimulate the social and spatial mobility of newcomers (Benton-Short \& Price, 2008; Bolt, Özüekren, \& Phillips, 2010; Saunders, 2011), finding inspiration in the notion of the urban 'zone of transition', initially coined by the Chicago School of Social Ecology in the 1930s. Such a spatial turn seems to resonate with the turn to space in migration studies which is proposed as a conceptual and empirical alternative to de-nationalise, de-'ethnicise' and de'migranticise' migration studies (Arnaut, Karrebæk, \& Spotti, 2016; Dahinden, 2016; Glick Schiller \& Çağlar, 2009, 2013). The 'infrastructuring of arrival' approach we propose in this paper builds further on the strengths of such a spatial approach.

\section{The neighbourhood approach: situating arrival in space and time}

The concept of 'arrival neighbourhoods' or 'urban zones of transition' is derived from the Chicago School of Social Ecology (1915-45). Drawing on detailed urban ethnographies and mapping a diversity of cities in North America, these early urban sociologists developed a 
conceptual framework that attempted to explain processes within cities - such as segregation, change and development. They viewed the city as an ecological system made up of interdependent components that reacted and adapted in uniform and highly predictable ways to changes in population, changes in the physical environment and wider external changes (Williams, 2016).

Their analysis suggested the city as zoned, arguing, for example, that certain neighbourhoods or zones were better equipped than other urban areas to accommodate newcomers and to allow them to climb the socioeconomic ladder in society (Burgess, 1925; McKenzie, 1924). Due to concentrated cheaper housing, the presence of ethnic institutions and the easy access to lowskilled (in)formal jobs these 'urban zones of transition' functioned as useful 'ports of first entry' for newcomers to establish themselves in a new context. What's more, the presence of particular institutions and social networks in these neighbourhoods also provided newcomers with the necessary skills and social networks to climb the American socioeconomic social ladder (Schillebeeckx, Oosterlynck, \& De Decker, 2019). This socioeconomic climbing consisted of a double: social climbing meant that newcomers to American society gradually became part of a (ethnically) diversifying American middle class. It also implied the gradual suburbanization of these groups, a sociospatial process Massey (1985) later coined as the process of 'spatial assimilation'.

The idea of the zones of transition still strongly influences present-day scientific debates on the role of the city in the process of arrival despite the critiques on the causal mechanisms that the Chicago sociologists initially identified to explain their existence (Sampson, 2012; Van Kempen \& Bolt, 2012). At this point, two observations are important for our discussion on the position and role of social work in the infrastructuring of arriving. First of all, one of the strengths of the 'urban transition zone' approach was that it situated the process of arrival in particular urban neighbourhoods: the 'ports of entry', the 'gateways' and more recent 'the neighbourhoods of arrival' or 'arrival cities' (Saunders, 2011). Such spatial grounding of the process of arrival has a number of advantages for social work, such as its explicit attention to the intersections of the lived and the built environment (Williams, 2016) and the possibility it implies for the organization of local street-corner work and other neighbourhood-based social development strategies (see Alinsky, 1946, on community organizing for example). Current repertoires in social work such as some forms of community work continue to build on this 
early imagination of the neighbourhood as a crucial place to work on forms of individual and collective social climbing across ethnic, cultural and administrative differences.

Limiting attention to the neighbourhood does become a problematic form of 'telescopic urbanism', however, when an exaggerated zooming in on the resources of the poor in the local community loses sight of the unequal power geometries (and urban and national welfare regimes) in which such neighbourhoods are positioned (Amin, 2013). Moreover, both migration and arrival neighbourhoods have for a long time been analysed almost exclusively as features of big cities, thus ignoring the dynamics outside or at the fringes of these areas (Boost \& Oosterlynck, 2019; Donato, Tolbert II, Nucci, \& Kawano, 2007; Funkhouser, 2000). Yet, migrants do not only end up in metropolitan neighbourhoods with large concentrations of newcomers, but also in other metropolitan quarters or in dispersed suburban and even rural settings (Alba, Logan, Stults, Marzan, \& Zhang, 1999; Massey, 2008; Singer, 2004). These processes of arrival do not come into view when using the lens of arrival neighbourhoods, which is a significant limitation of the concept, especially for social work with a focus on asylum seekers, who are often geographically dispersed to reception centres outside these 'neighbourhoods of arrival' (Schuermans et al., 2019).

A second major strength of the notion of the transition zone was its emphasis on the provisionality of arrival. Informality, insecure work, deviancy and moral dubiousness were seen as transitory phases in the trajectories of people passing through these areas. The discourse of transition was a hopeful counter narrative against fears for general societal collapse due to an unprecedented urbanisation pace and the disappearance of traditional rural Gemeinschaft. A hopeful message that 'zones of transition' were antechambers to a modern society yet to come. However, the centrifugal model of the Chicago School essentially described and to a certain extent helped legitimizing a teleological 'settlement' approach to migration (Collins, 2011, p. 316). The centrifugal model normatively represented settlement in the suburban middle-classes as the best outcome of migration, meaning that the 'port of first entry' necessarily precedes and shapes only one final destination: the suburban middle-class. In the provisional status of newcomers, their future trajectories were actually overdetermined: a permanent future in the national 'domos' (Walters, 2004). It is such a unidirectionality and teleology which is no longer (if it ever was) tenable. 
It is within these two domains that a focus on 'arrival infrastructures' can potentially expand the 'arrival neighbourhood' approach: (1) by proposing an alternative for its territorial limitations (the neighbourhood) through including all situated systems and moorings which enable and anticipate arrival, and (2) by opening up its teleological and normative underpinnings (antechamber before assimilation in the national domos) through a focus on how future pathways of social and spatial mobility are produced and negotiated in the process of arrival.

Larkin $(2013$, p. 328) defines infrastructures as '[...] built networks that facilitate the flow of goods, people, or ideas and allow for their exchange over space. [...] They comprise the architecture for circulation, literally providing the undergirding of modern societies [...]'. Applying this concept to the process of 'arrival', Meeus, van Heur \& Arnaut (2019) refer to those parts of the broader urban fabric in which newcomers become entangled on arrival and where their future local or translocal social becomings are produced as much as negotiated. Meeus and his colleagues approach 'arrival' in a Deleuzian way: arrival as a temporary materialization of being somewhere. Being, as phrased by Papadopoulos et al. (2008, p. 217) should be seen as 'nothing more than becoming's intermediate stages'. It is a temporary stage, 'the point of departure on which new becomings can emerge' (ibid), a phase during which future becomings are negotiated. These futures are theoretically unlimited, but in practice particular trajectories or vectors towards particular futures such as the route towards a suburbanised middle-class settlement in the 'transition zone' model, are usually hegemonic. In order to avoid reproducing such hegemonies, Meeus et al. (2019) discern three different dimensions to be taken into account when approaching the negotiation of 'being' somewhere: a politics of directionality (where will that future being be), a politics of temporality (when will that happen) and a politics of subjectivity (who will you be in the future). Arrival hence is not an endpoint, its entanglement with particular infrastructures creates both being and becoming.

An infrastructural approach to arrival retains the spatial dimension so important in the arrival neighbourhood theory and avoids a 'footloose networks' approach: social workers engage somewhere with people, they build up knowledge about the circumstances of arrival for particular groups in specific locations (Meyer, 1976). But the infrastructural language expands and refines the geographies of arrival beyond the territorial approach of the neighbourhood to all parts of the fabric of society that matter for newcomers. Just like the "neighbourhood of arrival' approach, it incorporates the informal and formal social networks and institutions 
relevant in the process of arrival, but without presupposing a particular spatial configuration or reach of these. The notion of infrastructure also includes the socially produced material artefacts such as procedures, documents, buildings and so on, which form part of the general urban infrastructure and which stabilise particular arrival normativities. Meeus and his colleagues (2019) emphasise that arrival infrastructures are the result of 'continuous infrastructuring practices' of a whole series of actors, often built up through generations of migrants. So, while migrants take local forms of being somewhere and prepare for future trajectories that can potentially take endless shapes, they face the durability of the artefacts and existing procedures and the particular (lack of) knowledge and skills of a wide range of actors: teachers, police officers, social professionals, citizens and many other informal actors.

Academic engagement with infrastructures has manifold histories and it is an impossible task to review all these rich lineages here. In the next section we will focus instead on some argumentations that have accompanied the more recent interest in infrastructure in anthropology, urban studies and migration studies, since we think they help to productively rephrase some of the concerns we raised in the sections above.

\section{Infrastructuring as a political practice}

An important long-standing interest in infrastructure emphasises the relations between infrastructure and state-power. Large technical systems transporting people, water, energy and waste do not only accelerate the mobility of these people and things, their architecture also has a 'poetic' role (Larkin, 2013). Because the building and maintenance of such infrastructures has been the prerogative of the state, their design was used to communicate progress, Modernity and the successfulness of the (nation-)state. Some argue that infrastructures are therefore 'a principle materialization of the relationship between people (citizens and non-citizens alike) and otherwise abstract state and supra-state authorities' (Dalakoglou, 2016, p. 823). Infrastructures are 'divination tools', their status gives clues about the status of the nation (Trovalla \& Trovalla, 2014, p. 2). In the post-war period, European nation-states at both sides of the Iron Curtain therefore invested in 'soft' and 'hard' infrastructures, providing a diversity of services to gain the consent of their citizens.

Driven by an ideological turn towards neoliberal forms of government all over Europe, the decade following the demise of state socialism saw a transition towards public-private 
partnerships in the provisioning of infrastructure, a period where private investors gradually acquired more decision power in which investments should and could be done. The 2008 financial crisis that hit European welfare states prepared a new phase of infrastructural disinvestment guided by an ideology of austerity, a phase that led to the further 'splintering' of urban infrastructures (Graham \& Marvin, 2001; Graham, 2010) and the appearance of what Dalakoglou (2016) calls 'infrastructural gaps'. In order to legitimise the growth of these gaps, Dalakoglou argues, European policy makers mobilised a diversity of discourses such as the 'Big Society' discourse in the UK and the 'participation society' in the Netherlands to pass on the responsibility to invest in and maintain soft and hard infrastructures to (non)citizens and corporate actors.

Investments in governmental 'asylum and refugee infrastructure' in Europe are a particular case in point in this evolution. While state-organised accommodation, detention and processing centres were mostly non-existent in the post-war period, from the 1990s onwards, the changing European migration regime resulted in an increased investment in border enforcement technologies on the one hand and a surveillance and accommodation infrastructure across European nation-states on the other (Popescu, 2011). The proliferation of numerous asylum, detention and processing centres across Europe aimed at providing basic services to 'processed' mobile people while keeping them within the surveillance realm of the state. However, in parallel with the more general withdrawal of the state from service provisioning, a gradual privatisation and corporatization of this service provisioning has been observed, bringing multinational corporations such as G4S and Serco into the field of forced migration and resulting in a further erosion of service provisioning (Darling, 2016). Such a growing 'infrastructural gap' in the field of migration leads, according to Kreichauf (2018), to a general process of 'campization' of the forced migration infrastructure across Europe. Investment priority is given to surveillance and containment and less to providing decent accommodation, advocacy and social support. The growth of infrastructural gaps, particularly in countries where austerity policies hit exceptionally hard, such as Greece, Portugal and Spain, however equally led to the rise of grass-roots infrastructuring activities spontaneously building their own infrastructures, developments in a later stage sometimes aided or co-opted by the state (Dalakoglou, 2016). The debate about the political role of such grassroots initiatives, we think, does not only mirror but potentially also inspires the debate about how to approach the manifold actors involved in offering support to asylum seekers, refugees and other displaced groups. 
This applies in particular to the 'poetic' role of infrastructures and their 'prefigurative' role: as experimental examples of how society’s arrival infrastructures could potentially take shape.

Writing from Johannesburg, AbdouMaliq Simone called to extend the notion of infrastructure to these continuous infrastructuring activities of diverse urban dwellers. He argued that conventional imaginaries of urbanization and the enchantment of Modern infrastructure portray African cities as 'in need of something that is not already present' (Simone, 2010, p. 6). While these discourses emphasise the lack of an 'appropriate' infrastructure, as a city full of 'infrastructural gaps', Simone points out that 'the capacities of large metropolitan areas - full of impoverishment and with uncertain futures - to persist [...] is a critical basis on which to build new institutions and collaborations' (ibid, p. 10). Without downplaying the role of the state in guaranteeing universal access to infrastructure, Simone (2004, p. 407) therefore calls attention to the 'ability of residents to engage complex combinations of objects, spaces, persons, and practices', since these are the conjunctions which 'become an infrastructure - a platform providing for and reproducing life in the city'.

Simone's call to extend the notion of infrastructure to people's activities in the city has been taken up by a number of scholars. In his work on 'infrastructuring the social', Rasmus Birk (2017) analyses social workers and community workers as 'infrastructurers', as circuits of circulation, entangled with materials and policies and attempting to rework agency. As such, he draws attention towards the practical work and normative hierarchies that are embedded in and enacted through practices of interventions. Silver (2014) expands upon the notion of 'incremental infrastructures' which are built by poor urban dwellers who are by necessity driven to partake in 'a constant and unfolding dialectic of adjustment and readjustment that may be unsanctioned and often officially (and in many cases arbitrarily) illegal' (2014, p. 790). He proposes to look at such incrementalism as 'experiments in material configurations that seek to test and prefigure new forms of infrastructure and accompanying resource flows' (ibid, p. 791). Amin (2014) emphasises even more the prefigurative dimension of the "lively infrastructures' built by disenfranchised communities in Brazil where '[...] in the making of the city along new lines - perhaps even for a fleeting moment - a new possible world emerges, new solidarities are formed, and the right of the disenfranchised to claim the city is claimed, exercised, and shown to be possible' (Amin, 2014, p. 160). It is this prefigurative dimension, the performative demonstration of 'new possible worlds' which can gradually build up societal consent, we think social work(ers) should be seeking in the infrastructuring of arrival that is 
already taking place, a position we will elaborate in the final section where we will focus on infrastructuring beyond sedentary logics.

\section{Infrastructuring arrival beyond sedentary and 'local' logics}

When it comes to debates on human mobility, a sedentarist lens is still omnipresent in the policymaking that produces and maintains most parts of the formal arrival infrastructure. Based on the conviction that resettlers will stay (forever) in their country of resettlement, they are often portrayed as a potential threat not only to the welfare state, but also to the cultural integrity and security of the context in which they end up (Popescu, 2011; Popescu \& Libal, 2018). Newcomers are designated as 'others' who need interventions to bring them in line with 'the rest of society', enabling and justifying interventions of the welfare state-materialised by professionals, policies, expertise and normative imperatives. As a result, different types of state infrastructures are developed to move people along specific - normative - trajectories (Birk, 2017).

In many European countries, newcomers are expected to demonstrate their intention to stay 'forever' and to prove their local ties in order to be able to use certain social benefits, such as public housing (Schuermans et al., 2019). Such normative trajectories, materialised in legislation, documents and procedures, contrasts strongly with the mobile lives that many (displaced) migrants lead. In reality, not all newcomers stay. In a globalised and superdiverse world, migration trajectories are inevitably becoming more complex. Many (displaced) migrants are highly mobile and follow a route with multiple movements from one country to another (or sometimes to different locations within the same country). This multiple mobility involves forms of circular migration, where migrants regularly commute back and forth between the temporary host country and their homeland, as well as more complicated migratory trajectories, for which the reasons and the destinations are not always known in advance (Schapendonk \& Steel, 2014; Schrooten, Withaeckx, Geldof, \& Lavent, 2016). Mobility is often characterised by a stronger perspective of transience: people do not always intend to stay permanently or even for a long period in any given country, but instead retain - whether through choice or necessity - a flexibility that better corresponds with their 'temporary' way of living (Morokvasic, 2004; Schrooten, Salazar, \& Dias, 2016; Schuster, 2005). 
For many social work organizations, this temporality forms a challenge. During an international workshop on 'Social work with highly mobile populations in times of refugee crisis' in November 2016, a social professional organising formations for migrants in a Swiss reception centre testified for example how his organisation had to completely change its modus operandi because of the increasing mobility of its participants. In the past, each course explored a key topic stretched over several months. In recent years, the social professionals had noticed that fewer and fewer participants succeeded in completing a full formation cycle. This had to do with the temporary nature of their stay in Geneva: numerous participants had often already left the city before the formation cycle was finished. Other social workers participating in the international workshop also confirmed that several of their clients suddenly left, sometimes to reappear unexpectedly at a later stage, and that this did not fit their usual way of working.

Many informal initiatives, on the other hand, do not consider the temporary presence of people and communities as a problem but rather as a starting point. They do not expect people to stay 'forever' but offer 'temporary' resolutions instead. Examples are the temporary residences offered to newcomers by religious organizations, citizen initiatives or individuals (De Gendt, 2014; Maskens, 2008) or the manifold forms of informal support that mushroomed all over Europe in the wake of the spectacularisation of migrant suffering in the public sphere from 2015 onwards. These informal initiatives can be approached as prefigurative of a new possible urban infrastructure that supports mobile populations beyond sedentary and nomadic notions of migration, since these set-ups are intriguing sites of encounter between locals, state employees and migrants where in the process of negotiating migrants' future pathways, imaginations of solidarity, citizenship, belonging and the nature of the nation state and the EU at large are at stake.

Another challenge for social work in its role as part of the arrival infrastructure is the discrepancy between on the one hand the local, Western focus and state-boundedness of social workers and the translocal lives of the newcomers they encounter on the other. Even though many of the current concerns of the profession of social work - such as social inequality, ecology, or human mobility - go beyond the particularity of nation-states and have an explicit translocal dimension, social work is just at its beginnings in systematically reflecting and analysing the significance of border-crossing developments (Furman, Negi, \& Salvador, 2010; Righard \& Boccagni, 2015). Highly significant in this matter is the 'methodological nationalism' (Wimmer \& Glick Schiller, 2003) at work in the field, meaning that the nation- 
state remains firmly embedded in social work concepts, policies and practices as an unquestioned frame of reference. Problem definitions, categories of analysis and methods of social work are still mostly situated within the context of the nation-state and its organizations and institutions, falling short in examining translocal processes and welfare institutions (Kettunen \& Petersen, 2011). Social work practices and policy are, for example, often predicated upon limiting notions and Western-inspired notions of a 'family'- nuclear and locally installed - and do not always grasp the implications of an embeddedness within transnational families in terms of mutual financial and caring responsibilities (Boccagni, 2015). The priorities set by social workers or their organizations can therefore be very different from those of their clients, as social workers are bounded by a legal framework - the existing infrastructure of procedures, documents and artefacts - that often focuses on local and individual support. Whereas this is not always the case for social workers, many informal actors that are part of the arrival infrastructure are well aware of the translocal embeddedness of migrants (Duffuor \& Harris, 2013; Mareels, 2016; Maskens, 2012). Because of the differences between formal and informal social work provisioners, they both have a specific role to play as arrival infrastructurerers.

\section{Conclusion}

This paper has engaged with the budding 'arrival infrastructures' framework to explore its potential use for social work theorization and practice. We have started the paper with the observation that formal social work only forms one of the many actors involved in the reception and everyday support of displaced people (see Phillimore, Bradby, Knecht, Padilla, \& Pemberton, 2019, for a similar approach on the topic of healthcare). In fact, newcomers face a number of situated systems and moorings, (social work) organisations and activities of diverse urban dwellers with which they negotiate their process of arrival. This empirical reality benefits from a conceptual framework that is able to analyse the process of arrival as it unfolds across this diversity in order to imagine and strategize the interventions social work could undertake. The broad focus on 'infrastructuring practices' that we propose adds to pre-existing literature that limit its scope to the role of specific actors, such as civil society or the state, in newcomers' reception.

Our argument builds further on the notion of the 'zone of transition' as introduced by Chicago School sociologists in the early 20th century. The major advantage of this notion, which 
somehow backgrounded in the second half of the previous century but seems to resurface now, is its focus on the multiple stages in the process of arrival and the 'institutional memory' of places: some places are better equipped to deal with newcomers than others since the locally present formal and informal forms of support have gradually built up specific knowledges and experiences. The framework of arrival infrastructures expands this strength, by opening up the normative approach to arrival heavily present in initial but also later uses and interpretations of the transition zone approach, and by diversifying the potential geographies of support.

Arrival, when conceptualised as encompassing both 'being' and 'becoming', then appears as a temporary stage, during which future becomings can be prepared. Arrival does however not occur in a void, since both being and becoming are shaped and channelled by infrastructures that facilitate certain forms of arrival and certain futures but equally discourage and underresource other forms of arrival and future becoming. These infrastructures themselves are 'infrastructured' by manifold actors who invent and shape new procedures, legislations and artefacts, or reproduce, maintain and repair existing ones. Particularly in the field of forced migration and displacement, nation-states, possessing the 'legitimate means of movement' (Torpey, 1998), have developed a range of infrastructures to control and process such populations, aiming to closely guard their trajectories of arrival. As the crisis of 2015 regarding the so-called 'boat people' in the Mediterranean has revealed however, the protracted underinvestment in these infrastructures has created numerous 'infrastructural gaps', some of which are filled by corporate actors, others which are filled by the infrastructuring activities of manifold others.

Building on recent debates in postcolonial urban studies, we have argued that social workers and social work theory should look for the prefigurative dimension in 'other' arrival infrastructures, the ways in which these infrastructures shape and channel the process of arrival beyond the sedentary and local logics predominant in current social work practice. Social workers can learn from the practices and geographies of these actors in a number of ways. A first point concerns the materiality of arrival infrastructures. Many informal networks and selforganizations have succeeded in focusing on basic needs, such as food distribution, the provision of public transport tickets (one of the most common reasons why people with precarious statutes are arrested), the distribution of clothing and especially the provision of showers and computers. Formal social work organisations do not always give priority to these matters. Secondly, while many professionals limit their activities to a well-defined area, 
informal initiatives pop up all over the country, within as well as outside traditional arrival districts. Now that the arrival function is much more than previously spatially distributed, it is crucial that formal initiatives also apply to this new geography of arrival. In parallel to this, social workers can also directly engage with informal arrival infrastructures, to not only investigate how trajectories are being shaped, how trajectories are being blocked and discouraged here (Meeus, 2018), but also to strategically introduce resources and knowledges that can open-up these blockages.

\section{Bibliography}

Alba, R.D., Logan, J.R., Stults, B.J., Marzan, J., \& Zhang, W. (1999). Immigrant groups in the suburbs: A reexamination of suburbanization and spatial assimilation. American Sociological Review 64, 446-460.

Alinsky, S. (1946). Reveille for radicals. Chicago: University of Chicago.

Amin, A. (2013). Telescopic urbanism and the poor. City, 17(4), 476-492.

Amin, A. (2014). Lively infrastructure. Theory, Culture \& Society, 31(7-8), 137-161.

Arnaut, K., Karrebæk, M., \& Spotti, M. (Eds.). 2016. Engaging superdiversity: Recombining spaces, times and language. Bristol: Multilingual Matters.

Beaumont, J., \& Cloke, P. (Eds.). (2012). Faith-based organisations and exclusion in European cities. Bristol: Policy Press.

Benton-Short, L., \& Price, M. (2008). Migrants to the metropolis: The rise of immigrant gateway cities, an introduction. In M. Price \& L. Benton-Short (Eds.), Migrants to the metropolis: The rise of immigrant gateway cities (pp. 1-22). New York: Syracuse University Press.

Birk, T. (2017). Infrastructuring the social: Local community work, urban policy and marginalized residential areas in Denmark. Environment and Planning A, 49(4), 767-783.

Blommaert, J. (2014). Infrastructures of superdiversity: Conviviality and language in an Antwerp neighborhood. European journal of cultural studies, 17(4), 431-451.

Boccagni, P. (2015). Burden, blessing or both? On the mixed role of transnational ties in migrant informal social support. International Sociology, 30(3), 250-268.

Bolt, G., Özüekren, A.S., \& Phillips, D. (2010). Linking integration and residential segregation. Journal of Ethnic and Migration Studies 36, 169-186.

Boost, D., \& Oosterlynck, S. (2019). "Soft" urban arrival infrastructures in the periphery of metropolitan areas: The role of social networks for Sub-Saharan newcomers in Aalst, Belgium. In B. Meeus, K. Arnaut, \& B. van Heur (Eds.), Arrival infrastructures: Migration and urban social mobilities (pp. 153-178). Cham: Palgrave Macmillan.

Burgess, E.W. (1925). The growth of the city: An introduction to a research project. In R.E. Park, E.W. Burgess, R.D. McKenzie (Eds.), The city (pp. 47-62). Chicago: University of Chicago Press.

Collins, F. (2011). Transnational mobilities and urban spatialities: Notes from the Asia-Pacific. Progress in Human Geography, 36(3), 316-335.

Dahinden, J. (2016). A plea for the 'de-migranticization' of research on migration and integration. Ethnic and Racial Studies, 39(13), 2207-2225. 
Dalakoglou, D. (2016). Infrastructural gap: Commons, state and anthropology. City, 20(6), 822-831.

Darling, J. (2016). Privatising asylum: Neoliberalisation, depoliticisation and the governance of forced migration. Transactions of the Institute of British Geographers, 41(3), 230-243.

De Gendt, T. (2014).Turkije aan de Leie. 50 jaar migratie in Gent. [Turkey on the Leie. 50 years of migration in Ghent]. Tielt: Lannoo.

Donato, K.M., Tolbert II, C.M., Nucci, A., \& Kawano, Y. (2007). Recent immigrant settlement in the nonmetropolitan United States: Evidence from internal census data. Rural Sociology, 72(4), 537-559.

Duffuor, A., \& Harris, A. (2013). Politics as a vocation: Prayer, civic engagement and the gendered re-enchantment of the city. Religion \& Gender, 3(1), 22-41.

Funkhouser, E. (2000). Changes in the geographic concentration and location of residence of immigrants. International Migration Review, 34(2), 489-510.

Furman, R., Negi, N., \& Salvador, R. (2010). An introduction to transnational social work. In N. Negi \& R. Furman (Eds.), Transnational social work practice (pp. 3-19). New York, Columbia University Press.

Glick Schiller, N., \& Çağlar, A. (2009). Towards a comparative theory of locality in migration studies: Migrant incorporation and city scale. Journal of ethnic and migration studies, 35(2), 177-202.

Glick Schiller, N., \& Çağlar, A. (2013). Locating migrant pathways of economic emplacement: Thinking beyond the ethnic lens. Ethnicities, 13(4), 494-514.

Graham, S. (Ed.). (2010). Disrupted cities: When infrastructure fails. New York: Routledge. Graham, S., \& Marvin, S. (2001). Splintering urbanism: Networked infrastructures, technological mobilities and the urban condition. London: Routledge.

Hannam, K., Sheller, M., \& Urry, J. (2006). Editorial: Mobilities, immobilities and moorings. Mobilities, 1(1), 1-22.

Kettunen, P., \& Petersen, K. (2011). Beyond welfare state models: Transnational historical perspectives on social policy. Cheltenham: Edward Elgar.

Kreichauf, R. (2018). From forced migration to forced arrival: The campization of refugee accommodation in European cities. Comparative Migration Studies, 6(1), 7.

Larkin, B. (2013). The politics and poetics of infrastructure. Annual review of anthropology, 42, 327-343.

Mareels, E. (2016). Des portes de la ville à la conquête des nations: Spiritualisation du local et du global chez les pentecôtistes brésiliens de Bruxelles. [City gateways to the conquest of nations: Spiritualization of the local and the global among the Brazilian Pentecostals of Brussels]. Religiologiques, 33, 125-154.

Maskens, M. (2008). Migration et pentecôtisme à Bruxelles: Expériences croisées. [Migration and Pentecostalism in Brussels: Combined experiences]. Archives de Sciences Sociales Des Religions, 143, 49-68.

Maskens, M. (2012). Spiritual geographies: Mobility of Pentecostal ministers and migratory "miracles" between Africa or Latin America and Europe. Brussels Studies, (58), 13.

Massey, D.S. (1985). Ethnic residential segregation: A theoretical synthesis and empirical review. Sociology and Social Research, 69(3), 315-350.

Massey, D.S. (Ed.). (2008). New faces in new places: The changing geography of American immigration. New York: Russell Sage Foundation.

McKenzie, R.D. (1924). The ecological approach to the study of the human community. American Journal of Sociology 30, 287-301.

Meeus, B. (2017). Challenging the figure of the 'migrant entrepreneur': Place-based solidarities in the Romanian arrival infrastructure in Brussels. In S. Oosterlynck, N. 
Schuermans, \& M. Loopmans (Eds.). Place, diversity and solidarity (pp. 103-120). Oxon: Routledge.

Meeus, B. (2018). Platforms to stand on for a while. Re-imagining the city (Brussels) from an arrival infrastructure perspective. Paper presented at the Jahrestagung der ÖFEB-Sektion Sozialpädagogik 20./21. September 2018, Universität Salzburg.

Meeus, B., van Heur, B., \& Arnaut, K. (2019). Migration and the infrastructural politics of urban arrival. In B. Meeus, K. Arnaut, \& B. van Heur (Eds.), Arrival infrastructures: Migration and urban social mobilities (pp. 1-32). Cham: Palgrave Macmillan.

Meyer, C. (1976). Social work practice: A response to the urban crisis. New York: Free Press. Morokvasic, M. (2004). 'Settled in mobility': Engendering post-wall migration in Europe. Feminist Review, 77(1), 7-25.

Papadopoulos, D., Stephenson, N. \& Tsianos, V. (2008). Escape routes. Control and subversion in the twenty-first century. London: Pluto Press.

Phillimore, J., Bradby, H., Knecht, M., Padilla, B., \& Pemberton, S. (2019). Bricolage as conceptual tool for understanding access to healthcare in superdiverse populations. Social Theory \& Health, 17(2), 231-252.

Popescu, G. (2011). Bordering and ordering the twenty-first century: Understanding borders. Lanham: Rowman \& Littlefield Publishers.

Popescu, M., \& Libal, K. (2018). Social work with migrants and refugees. Challenges, best practices, and future directions. Advances in Social Work, 18(3), i-x.

Raithelhuber, E., Sharma, N., \& Schröer, W. (2018). The intersection of social protection and mobilities: A move towards a 'Practical Utopia' research agenda. Mobilities, 13(5), 685-701.

Righard, E., \& Boccagni, P. (2015). Mapping the theoretical foundations of the social work migration nexus. Journal of Immigrant \& Refugee Studies, 13(3), 229-244.

Sampson, R.J. (2012). Great American city: Chicago and the enduring neighborhood effect. Chicago: Chicago University Press.

Saunders, D. (2011). Arrival city: How the largest migration in history is reshaping our world. London: Windmill books.

Schapendonk, J., \& Steel, G. (2014). Following migrant trajectories: The im/mobility of SubSaharan Africans en route to the European Union. Annals of the Association of American Geographers, 104(2), 262-270.

Schillebeeckx, E., Oosterlynck, S., \& De Decker, P. (2019). Migration and the resourceful neighborhood: Exploring localized resources in urban zones of transition. In B. Meeus, K. Arnaut, \& B. van Heur (Eds.), Arrival infrastructures: Migration and urban social mobilities (pp. 131-152). Cham: Palgrave Macmillan.

Schrooten, M. (2012). Moving ethnography online: Researching Brazilian migrants' online togetherness. Ethnic and Racial Studies, 35(10), 1794-1809.

Schrooten, M., Salazar, N.B., Dias, G. (2016). Living in mobility: Trajectories of Brazilians in Belgium and the UK. Journal of Ethnic and Migration Studies, 42(7), 1199-1215.

Schrooten, M., Thys, R., \& Debruyne, P. (Eds.). (2019). Sociaal schaduwwerk. Over informele spelers in het welzijnslandschap. [Social work in the shadow. About informal actors in social work]. Brussel: Politeia.

Schrooten, M., Withaeckx, S., Geldof, D., \& Lavent, M. (2016). Transmigration: Social work in a world of superdiversity. Leuven: Acco.

Schuermans, N., Schrooten, M., \& De Backer, M. (2019). Informele en formele sociaalwerkpraktijken als aankomstinfrastructuren voor nieuwkomers. [Informal and formal social work practices as arrival infrastructures for newcomers]. In M. Schrooten, R. Thys, \& P. Debruyne (Eds.), Sociaal schaduwwerk. Over informele spelers in het welzijnslandschap. (pp. 147-158). Brussel: Politeia. 
Schuster, L. (2005). The continuing mobility of migrants in Italy: Shifting between places and statuses. Journal of Ethnic and Migration Studies, 31(4), 757-774.

Simone, A. (2004). People as infrastructure: Intersecting fragments in Johannesburg. Public culture, 16(3), 407-429.

Simone, A. (2010). The social infrastructures of city life in contemporary Africa. Uppsala: Nordiska Afrikainstitutet.

Silver, J. (2014). Incremental infrastructures: Material improvisation and social collaboration across post-colonial Accra. Urban Geography, 35(6), 788-804.

Singer, A. (2004). The rise of new immigrant gateways: The living cities census series. Washington, DC: Brookings Institution Press.

Törngren, S.A., Öberg, K., \& Righard, E. (2018). The role of civil society in the integration of newly arrived refugees in Sweden. In A. Lāce (Ed.), Newcomer integration in Europe: Best practices and innovations since 2015. (pp. 13-24). Brussels: Foundation for European Progressive Studies.

Torpey, J. (1998). Coming and going: On the state monopolization of the legitimate "means of movement". Sociological theory, 16(3), 239-259.

Trovalla, U., \& Trovalla, E. (2015). Infrastructure turned suprastructure: Unpredictable materialities and visions of a Nigerian nation. Journal of material culture, 20(1), 43-57.

Valtonen, K. (2016). Social work and migration. Immigrant and refugee settlement and integration. London: Routledge.

Van Dam, S., \& Raeymaeckers, P. (2017). Migrants in the periphery: Migrant organisations and their networks. European Journal of Social Work, 20(6), 921-934.

Van Kempen, R., \& Bolt, G. (2012). Social consequences of residential segregation and mixed neighborhoods. In F. Clapham, W. Clark, \& K. Gibb (Eds.) The SAGE Handbook of Housing Studies (pp. 439-460). Thousand Oaks: Sage.

Walters, W. (2004). Secure borders, safe haven, domopolitics. Citizenship studies, 8(3), 237260.

Williams, C. (2016). Social work and the city. Urban themes in 21st-century social work. London: Palgrave MacMillan.

Wimmer, A., \& Glick Schiller, N. (2003). Methodological nationalism, the social sciences, and the study of migration: An essay in historical epistemology. International Migration Review, $37(3), 576-610$. 